\title{
Obituary
}

Sir Frederic Nathan, K.B.e.

COLONEL SIR FREDERIC LEWIS 4 NATHAN died on December 10 at the age of seventy-two years. As a young artillery officer who had passed through the advanced class of the Ordnance College, Capt. F. L. Nathan, as he was then, was detailed to take part in the experimental work of Abel, Dewar and Kellner, who were bringing out at Woolwich the smokeless propellant cordite. He was thus at the birth of that explosive, to the improvement and manufacture of which he was to devote his energies between 1892 and 1909 at the Royal Gunpowder Factory, Waltham Abbey, as Assistant- and then as Superintendent. During these years it can fairly be said that a new technique was introduced into the manufacture of explosives. The methods of Waltham Abbey were adopted by the then numerous private firms making explosives, while later the propellant factories erected during the War embodied the features of Waltham Abbey practice.

The improvements made during this time included a reorganisation of the work of the factory, to which Sir Frederic devoted the energy of a logical and business mind, the invention and introduction of new processes of manufacture of cordite and its ingredients, the study of danger precautions in manufacture on which he became an authority, and the recognition of the importance of investigative work.

Having raised the Royal Gunpowder Factory to the highest pitch of efficiency, Sir Frederic retired from the Army to apply his methods to the Nobel factory at Ardeer, of which he was works manager from 1909 until 1914, and in March 1915 he was appointed adviser to the Admiralty on cordite supply when he was given the task of designing and laying out the Royal Naval Cordite Factory at Holton Heath. Here, on an open area, unencumbered by ancient water-ways and existing buildings as at Waltham Abbey, he had free scope to erect a magnificent propellant factory such as would embody his experience of process and study of precautions for safety, and in which there was orderly progress from raw to finished material. This having been completed and put into operation, Sir Frederic became Director of Propellant Supplies under Lord Moulton.

After the War Sir Frederic concerned himself for a time with the safety of explosives in coalmines, and as a member of the Department of Scientific and Industrial Research he gave his attention to the possibilities of home-produced alcohol as a motor fuel, and later to fuel research, for which he was the Department's Intelligence Offieer up to the date of his death. In this capacity he applied himself to the extraction of what was relevant in the literature and to the best methods of indexing it. $\mathrm{He}$ was also chairman of the Association of Special Libraries and Information Bureaux (A.S.L.I.B.), editor of a British Power and Fuel Bulletin issued by the World Power Conference, and projected at the time of his death the publication of an International Power and Fuel Bulletin in three languages, indexed according to the decimal classification of the Institut International de Bibliographie.

Among other activities should be mentioned Sir Frederic's interest in the training of the chemical engineer, this being the title of his presidential address to the Institution of Chemical Engineers, of which he was one of the founders and twice president. He was also Commandant of the Jewish Lads' Brigade for twenty-one years. He was knighted in 1906 and became K.B.E. in 1918. Lady Nathan and three sons survive him. His third son was killed in action on June 14, 1917.

Those who came into contact with Sir Frederic Nathan could not fail to recognise his high ideals, his great industry and his methodical mind; those who had the good fortune to work with him found in him an inspiration and constant support in the appreciation and furtherance of their scientific work. ROBERT ROBERTSON.

\section{Mr. A. E. P. WEIGaLL}

WE regret to record the death on January 2 at the age of fifty-three years of Mr. Arthur Edward Pearse Weigall. Mr. Weigall was the son of Major A. A. D. Weigall. He matriculated as a member of the University of Oxford from New College in 1900; but after a brief residence joined Sir Flinders Petrie's staff for archæological exploration at Abydos in Egypt. In 1905 he was appointed Inspector-General of Antiquities under the Egyptian Government, a post which he held until 1914. His archæological work was recognised by his appointment as officer of the orders of the Red Eagle (Germany), Franz Josef (Austria), and the Medjidieh (Egypt).

Weigall was a prolific and versatile writer, his work ranging from the record of archæological investigation to the purely imaginative effort of novel writing. His gifts were perhaps most happily displayed in the imaginative interpretation of archæological and historical data as in his "Life of Akhnaton, Pharaoh of Egypt" (1910) and "Life of Cleopatra, Queen of Egypt" (1914). Among his numerous archæological and historical works may be mentioned :- "Abydos" (sections of) Parts 1 and 2 (1902 and 1904), "Report on the Antiquities of Lower Nubia" (1907) ; "Catalogue of Weights and Balances in the Cairo Museum" (1908); "A Guide to the Antiquities of Upper Egypt" (1910) ; "The Treasury of Ancient Egypt" (1911) ; "Tutankhamen and other Essays" (1923) ; "A History of the Pharaohs" (1925-26) and with A. H. Gardiner "Topographical Catalogue of the Private Tombs of Thebes" (1913). He was also the author of a book of travel, "Travels in the Upper Egyptian Deserts" (1909). 